\title{
FAMILY PLANNING IN ISLAM
}

\author{
Naqiyah \\ STAIN Purwokerto \\ Jl. Jend. Ahmad Yani No. 40 A Purwokerto \\ Email: Naqiyah.mukhtar2@gmail.com
}

\begin{abstract}
Abstrak
Terdapat kontroversi di kalangan para ulama tentang keluarga berencana (KB) dalam Islam. Sebagian menyatakan bahwa keluarga berencana itu boleh, tetapi sebagian memandangnya tidak sesuai dengan ajaran Islam. Di samping itu, ia dicurigai sebagai agenda tersembunyi asing (non muslim). Selain itu, KB dicurigai karena berasal dari negara asing yang (mayoritas non - Muslim ) dengan agenda yang tersembunyi untuk melemahkan umat Islam. Jadi, apa substansi keluarga berencana? Apakah metode dalam melakukannya? Apa tujuan melakukannya? Lalu, bagaimana jika hal ini dikaitkan dengan ekonomi dan ekosistem? Siapa yang berhak untuk menentukan pelaksanaan keluarga berencana? Apa keluarga berencana dalam hukum Islam? Tulisan ini akan membahas hal-hal tersebut dengan menggunakan metode deskriptif dan analisis terhadap argumen yang diajukan oleh kedua kalangan baik yang menerima maupun yang menolak. Penulis berpendapat bahwa dalam kondisi yag sangat tidak seimbangan antara pertumbuhan populasi manusia dan ekosistem, keluarga berencana tidak hanya diperbolehkan tetapi dapat diwajibkan oleh Pemerintah sebagai wakil dari masyarakat.
\end{abstract}

Kata kunci: keluarga berencana, hukum Islam, populasi, ekonomi, ekosistem

\begin{abstract}
There is a controversy amongst Islamic scholars regarding family planning in Islam. Some believe that it is lawful, while the rests consider that this is not in accordance with the teachings of Islam. In addition, it is suspiciously considered as a foreign (non-Muslims) hidden agenda to weaken the Muslims. So, what is the substance of the family planning? What is the method in doing so? What is the purpose of doing so? Then, how if it is linked to economic and ecosystem? Who has the right to determine the implementation of family planning? What is family planning in Islamic law? This paper addresses these issues by using descriptive and analytical method to the arguments put forward by both people who accept and those who reject. I argue that in the conditions of extreemely inbalance between the human population growth and the ecosystem, the family planning is not only allowed but it must be obligated by the Government as a representative of the community.
\end{abstract}

Keywords: family planning, Islamic law, population, economy, and ecosystem 


\section{A. Introduction}

Although family planning (KB) in Indonesia has long been implemented as a national program and accepted by most Indonesian people, however, lately it has often become a controversial issue. This controversy could weaken the commitment of the people in implementing the family planning, so it would in turn have an impact onthe high rate of population growth. As a consequence, this would worsen the social, economical and environmental conditions. Although it is well recognized that the increasing percentage theproductive age in the population can be considered as an economical capital, on the other hand,if the government is unable to provide jobs anda means of self-actualization, this will have an impacton the social stability.

The controversy about the family planning happens because some people think that there are some issues on family planning program in relation to Islam. Among these are: the substance of the family planning, birth regulation or birth restriction, the method of the family planning, the purpose or motivation, what is the population, economy, and ecosystem, who has the right to decide the implementation of the family planning, and the context of family planning in Islamic law. This paper will address these issues by using descriptive analytical method to the arguments used by the people who accept and by those who reject the family planning.

\section{B. Definition, Method, and Purpose of the Family Planning}

1. The family planning definition

There are some meanings presented by experts on family planning. Among these are: Family planning is an effort to increase public awareness and participation through the maturation age of marriage, birth control, fostering family resilience, family welfare improvement prosperous in creatinga prosperous happy small family. ${ }^{1}$ Family planning or planned parenthood, is an attemptto plan the number or increase spacingof pregnancies by using contraception. Thisisan attempt to help individuals orcouples to: get certain objects, avoid unwanted births, get the expected birth, set the interval between pregnancies, and determine the number of children in the family. ${ }^{2}$

In Islamic literature there are two terms on family planning, the tanżìm alnasl (birth control) andtahdid al-nasl (birth limitation). The first(tanzim alnas) regulates pregnancy by using various ways which can prevent pregnancy, with the aim to prevent pregnancy in acertain period of time because of the beneficiaries. While the second (tahdid al-nast) is to prevent pregnancy forever that may cause infertility (ta'qīm) and orabortion(isqâtalhaml).

In practice, family planning generally means aconcrete planning of married couples about when to get pregnant, how many children they want according to their capacity, the situation and the condition of the society and the country,with a variety of waysand tools such ascondoms, IUDs, contraceptive pills, and so on. If it is associated with Islamic reference, the family planning practically in Indonesia can be categorized to the tanzim al-nasl (birth control), in addition to the tahdìd al-nasl (birth limitation). Eventhough in the beginning they tend to do tanzim al-nasl, but when they have the desired children, they incline to do the tahdid al-nasl.The family planning is a national government program in many countries to regulate the balance between the population and the availability of jobs and national economic growth. This might basedonThomas Robert Malthus's population theory which predicts that national population growth is not balanced with the availability of jobs and economic growth. 
2. The familiy planning method

There are several methods of contraception, including the following: ${ }^{3}$

a. Simple method:

-Without tools: (1) natural family planning, with the calendar method (Ogino Knaus), basal body temperature (thermal) method, cervical mucus method (billings), and thermal Sympto method, and (2) KB coitus interruptus.

-With tools: (1) Mechanical (barrier): (a) condoms for men and (b) intra-vaginal barrier, namely the diaphragm, cervical cap (cervical cap), sponge (sponge), condoms for women, and (2) chemical (spermicides): (a) vaginal cream (b) vaginal suppositories

b. Modern methods:

-hormonal contraception: (1) oral pill,(2) injection,(3) sub cutis (implants),

-Intra-uterine devices (IUD), and

-Permanent contraception (MOW// MOP)

The contraception method works by preventing the sperm from reaching and fertilizing the egg (fertilization) or preventing the fertilized egg from implantation (attachement) and developing in the womb. In general, there are two kinds of contraception: reversible and permanent (fixed) contraception. The first one is a method of contraception that can be terminated at any time without any effect on the ability to restore fertility to have more children. While the second one or what we call sterilization is a contraceptive method that cannot be restored due to involved surgery. If it is associated with the notion of family planning in Islamic literature, the reversible contraception can be categorized as a birth control, while permanent contraception can be classified as a birth limitation.

3. The purpose of family planning

The purpose of the family planning in general is to control the number of births and the distance between the child's birth. In detail, the purpose of a family planning is usually expressed as follows: a. A family with an ideal son/doughter, b. a healthy family, c. an educated family, d. a prosperous family, e. family resilience, f. a family that its reproductive right is fulfilled, and $\mathrm{g}$. the balanced population growth. ${ }^{4}$ In conclusion, the family planning is birth control or birth limitation either by using temporary (reversible) or permanent contraception, for the purpose as previously mentioned.

\section{The Population, Economic, and Ecosystem}

It is commonly said that a population can be described as a doubleedged knife. On one side, alarge population with low quality people will heavily burden the economic development, on the other hand,a large population with good quality people will become an asset that is very beneficial for the economic development. Until 1970s, there were twoviews on the impact of population growth on the economic development.The first view(pessimistic) states that rapid population growth can lead to poverty, under development and famine, as a result of the depletion of natural resources, environmental degradation, and ecological destruction. This is in accordance to Ehrlich and Ehrlich (2009) who state that:

" "Human beings and the natural world are on a collision course. Human activities inflict harsh and often irreversible damage on the environment and on critical resources. If not checked, many of our current practices put at serious risk the future that we wish for human society and the plant and 
animal kingdoms, and may so alter the living world that it will be unable to sustain life in the manner that we know. Fundamental changes are urgent if we are to avoid the collision our present course will bring about.",

On the other hand, the second view (optimistic) states that a rapid population growth is an asset that can lead to the improvement of social conditions that may promote economic development, technological and institutional innovation. $^{6}$ The latter view is empirically proven in several countries such as Singapore, Hong Kong, Korea, Taiwan, Japan, and most of the developed countries in the world eventhough they do not have much natural resources, but they can grow and thrive because they have high quality human resources.

What about these issues in Indonesia? The quality of the Indonesian people as measured by the Human Development Index is low. In 1996, for example, Indonesia ranks 102; then, in 2000 it did not show an increase, even dropped to the level of $109^{7}$. Furthermore, in 2003, the quality of human resources based on the assessment of UNDP, was ranked 112 of 175 countries in the world. ${ }^{8}$ Then, on July 14 , 2014, the United Nations Development Programme ( UNDP ) released the data is that Indonesia's position is still the same as the previous year ( 2013 ) which is at position 108 of 187 countries in the world , which is located below the position of Singapore which is ranked 9, Brunei 30, Malaysia 62, and Thailand 89. The other ASEAN member countries lower ranks with Myanmar on the ranking of 150 , Laos 139, 136 Cambodia, Vietnam 121, and the Philippines $117 .{ }^{9}$

Regarding the population size, "A great number of people would be good if the quality of human resource is high, but in fact the quality of the Indonesian people is a concern. Furthermore, a large population size, with low quality people will affect the carrying capacity of the environment ${ }^{10}$. Indeed,several studies from the year 2000 has obtained the following conclusions: 1 . That the magnitude of population growth was negatively correlated to the rate of economic growth. 2. Rapid decline of fertility contributed significantly topoverty reduction. In conclusion, the high fertility in developing countries is one ofthe causes of poverty, both at the family (micro) and at the state (macro) level. ${ }^{11}$ That's why, nowthere is a consensus among the experts that high population growth not only negatively impacts food supplies, but also hinders the economic and human resource development. The human population on Earth in 2000 has exceeded 6 billion people. In August 2013 reached 7.2 billion people, and is estimated to reach 8 billion people by the year 2020, and 10.9 billion in the year $2100 .{ }^{12}$ To support such a hugh human number,the earth load will be too heavy, especially in supplying natural resources, inproviding good quality environment, and livability for its residents.

Although the Population Bomb has been both praised and vilified, but there is no controversy over its significance to demographic issues. So, what isthe responsibility of human beings to their environment? They must respond to the problems of environmental sustainability of the earth, by taking any action to save the earth to keep the capacity of the environment tin order to performits functions properly as a harmonious global ecosystem. One of its solution is birth control, because a population explosion will inevitably increase pollution and environmental damages, food shortages, harm the health, make difficulty in obtaining adequate housing, and may increase in unemployment, poverty, famine crime, and war. 


\section{Family Planning and Islam}

1. The Decision Maker of Family Planning

Among the frequently debated aspects of family planning in Islam is about who has the right to decide to have children? According to Mahmud Syaltut there are fou ropinions among scholars: first, the father (husband) has theright to decide to have descendants as proposed by al-Ghazali (d. 505H.). Second, both parents (husband and wife) jointly have the right to decide to have descendants as presented by the Hanafiyyah. Third, both parents (husband and wife) andsociety (the government) have the right to determine the children, but the rights of both parents is greater than the rights ofthe society, asexpressed by the Shafi'iyah, Hanabilah, and jumhur ulama'. Fourth, like the third opinion, the right of the government is greater than theright of both parents, as espouse by the scholars of Hadith. ${ }^{13}$

The first opinion states that the right to decide to have children belongs to the husband. It means thata wife may not refuse to get pregnant if her husband wants her to. In fact, in the Qur'an alBaqarah2 verse 233 (two), it is stated that to wean the child before two years old was ordered to be deliberated between husband and wife. ${ }^{14}$ Al-Razi asserted tha childrens hould not beweaned before two years old unless with the willingness of their parents through deliberation. ${ }^{15}$ Where as, it is uneasy for a woman(wife) to be pregnant, to give a birth, to lactate and so forth. Therefore, it is unfair to give the right only tothe husband who does not directly burdened by pregnancy, breastfeeding, and so forth.

Furthermore, for the second opinion which leaves the decision to have children to the spouses is more acceptable, because it is not only that the children inherit husband's sperm and wife's ovum, but also that the one who bears the burden of pregnancy and lactation is the wife, the breadwinner is the husband, and both husband and wife grow up the children. Thus, both husband and wife deserve the right to decide to have children or not. Moreover, the Qur'an itself asks husband and wife to reason in family matters, such as for weaning children, as has been stated in the previous section.

Then, what about the third opinion that the decision to have offspring not only in the hands of husband and wife, but also in the hands of the society (which in this case can be represented by the government), although the spouses right is greater than the community (the government) rights? Likewise, the fourth opinion, but the right of people is greater than the right of husband and wife? The two last opinions are interesting to be explored, especially the last one. If having or not having children is only handed or emphasised on the personal wills (husband and wife), then it is not fair, while it is strongly related to the public goodness or harm, so the main priority is for public interest. For example, if the right to have offspring that is clearly associated with the population problem in one state is given to personal (husband and wife), then it will be difficult to control a personal will when it is not accompanied by social awareness. Thus,something that is strongly connected to demographic problem should not be detemined bypersonal will.

2. Family Planning in Islamic Law

Scholars differ in their views regarding the family planning in Islamic law. Some state that family planning is allowed, because it is not clearly regulated both in the Qur'an and the Sunnah. In a prinsiple (kaidah), it is الدليل على الاصل فن الاشياء الاباحة حتى يدل stated that تحريمها (everything is principally allowed except if there is an argument that prohibit it). Some others declared that the law of family planning is unlawful 
because it is not in agreement to the directions of Islamic law that prohibits the act tabattul (single life forever). So, there are various scholars views about the family planning: ranging from unlawful, lawful with some conditions, and fully lawful.

Some scholars who argued that the family planning is prohibited, stated that Islam forbids men to be single and orders them to marry women who are fertile in order to have many children so that the Prophet will be proud to have many ummah in the hereafter. Muslims need not to fear of poverty because Allah guarantees fortunes. The arguments put forward were as follows:

a. Allah forbids men to be single, as in the Hadith.

... Ibrahim bin Sa'd ... has apprised to us Ibn Shihab has heard to Sa'id ibn al-Musayyab that said, I heard Sa'd ibn Abi Waqqas said, the Messenger of Allah saw. prohibited to 'Uthman ibn Maz'ūn of celibacy (tabattul), and if the Prophet permitted him undoubtedly we will do castration (al-ikhtisa $\vec{a}){ }^{16}$

b. Tthe purpose of marriage is to have children, as in al-Nahll16: 72 ,

"And Allah has made for you mates (and companions) of your own nature, and made for you, out of them, sons and daughters and grandchildren, and provided for you sustenance of the best: will they then believe in vain things, and be ungrateful for Allah's favours? ${ }^{17}$

c. The above verse is reinforced by the following Hadith,

...From $\mathrm{Mu}^{\text {'awiyah bin }}$

Qurrat from Ma'qil bin Yassar he said: A man came (to see) the Messenger of Allah and said: "I am getting a woman (derived from) the honorable descent and has a beauty, but she can not have children (infertile), May I marry her? "the Messenger of Allah replied: "Do not (be)", then the man came (and ask again) for the second time, then the Messenger of Allah reforbided, then the man came (and ask again) for the third time, the Prophet said: "Marry women who are loving and fertile (many children), for verily I will boast (the large number of guys) in the presence of other peoples (on the Day of Resurrection)."18

d. Allah has guaranteed to give sustenance to the human beings and even to the animals

There is no moving creature on earth but its sustenance depends on Allah: He knoweth the time and place of its definite abode and its temporary deposit: All is in a clear Record. $^{19}$

The verse is supported by the following verses

Say: "Come, I will rehearse what Allah hath (really) prohibited you from": Join not anything as equal with Him; be good to your parents; kill not your children on a plea of want;- We provide sustenance for you and for them;come not nigh to shameful deeds. Whether open or secret; take not life, which Allah hath made sacred, except by way of justice and law: thus doth $\mathrm{He}$ command you, that ye may learn wisdom (alAn'am/6:151). ${ }^{20}$

Kill not your children for fear of want: We shall provide sustenance for them as well as for you. Verily the killing of them is a great $\sin (a-I s r a ̄ ' / 17: 31){ }^{21}$

Such arguments presented by those who refuse the family planning and see it as a forbidden (haram) in Islam.

The scholars who allow family planning argue that:

a. This is the verse that has to be understood that we have to pay attention to the future, 
O ye who believe! Fear Allah, and let every soul look to what (provision) $\mathrm{He}$ has sent forth for tomorrow. Yea, fear Allah: for Allah is well-acquainted with (all) that ye do. ${ }^{22}$

b. we are allowed to do 'azal in the hadith, so some scholars use qiyas, when 'azl is allowed, then other methods of birth control effort was certainly permitted.

"... Jabir said:" We did 'azal while the Quran is still down. Also it is be told from 'Amr from 'Ata', from Jabir, he said: "We did 'azal at the time of the Prophet., while the Qur'an is still down ${ }^{23}$

c. the Qur'an (al-Nisā'/4:9) demands us not to leave weak offspring,

"Let those (disposing of an estate) have the same fear in their minds as they would have for their own if they had left a helpless family behind: Let them fear Allah, and speak words of appropriate (comfort). ${ }^{, 24}$.

d. the Qur'an (al-Baqarah/2: 195) orders us to keep away from damage,

"And spend of your substance in the cause of Allah, and make not your own hands contribute to (your) destruction; but do good; for Allah loveth those who do good." 25

From the above arguments, it appears that the legal origin of the family planning is actually "allowed" based on the verses of the Qur'an and some Hadiths that instruct us to pay attention to the future, allowing to do 'azal, leaving no weak descendants, and keep away from annihilation.

3. Analysis of the views on family planning

The view that prohibit family planning based on the argument for the prohibition of the Prophet Companions to do tabattul. Tabattul etymologically means people who decide and separate themselves from worldly life to worship God, not married (single), ${ }^{26}$ rugged woven wear, deny good food and clothes, castrate themselves, Qiyām al-Lail, and fasting. ${ }^{27}$ So, tabattul abstain from worldly life in some ways that deny lawful things, in order to worship God. Otherwise, one of the purposes of marriage is to worship, as mentioned in the hadith, (the one who married, then he has perfected his half faith, then let him look after himself on the other half). ${ }^{28}$

The argument that the purpose of getting married is to have children, so it is not allowed for a person to marry an infertile woman, need to be discussed further. Because the purpose of marriage is not only to have descendants, but also for other goals, such as to worship God, to prove love, to fulfil the bological needs, to protect each other (as husband and wife), and to become an educational institution. ${ }^{29}$ The Prophet's "prohibition" to men to marry infertile women as mentioned in the above riwayah. should not be understood as a prohibition that it is unlawful, but it should be assumed with it is better to get married with a fertile women. Principally, the reason put forward to the Prophet by the man regarding the honor and beauty of a woman, is not about the religion of her as emphasized by the Prophet in one riwayah. ${ }^{30}$ If the motivation of that man proposed to the Prophet was the woman's religion, the Prophet might not likely to disallow it.

Furthermore, the argument that "There is no moving creature on earth but its sustenance dependeth on Allah (Hīd/11: 6)," should be understood that the nourishment from God is not always given for free. So God may or may not give the sustenance, so then there is a possibility that human and or animal are to get starved. ${ }^{31}$ In fact, in Indonesia, for example, till today there is a famine, 
though Indonesia today have succeeded in reducing the number of people suffering from hunger, 37 million people in 1990 to 21 million in 2012, or only reached 43.8 percent. $^{32}$

Then, the verse 151 of surah al$A n ' \bar{a} m$ and 31 al- Isra talks about the prohibition to kill children for fear of poverty, whereas God will give sustenance (rizq). Family planning is not synonymous with murder, because it is neither abortion nor murder. The verse also states "nahnu narzuqukum (we will give you sustenance). The use of the word we shows that there is involvement of other parties (in this case human being), not just God that givessustenance,so, family planning or birth control oreven birth limitation (under certain conditions) can be part of the effort to acquire sustenance that has been provided by God .

Then, what about the arguments put forward by people who support family planning programsbased on the verses of the Qur'an and Hadith that instructed us to pay attention to the future, allowing to do 'azal, leaving no weak descendants, and keep away from harm.

A Qur'anic verse which states that "... let every soul consider what he has done for tomorrow (Hereafter) (Sura 59:18)," does not really talk about a family planning, but speaking in a general context that each individual need to evaluate the deeds that he had done and then prepare himself with righteous activities to the afterlife. Ibn Kašīr, for example, explains that this verse contains the message: that human beings have to account their deeds, before calculating his credit in the end of the day. Also, that the human have to introspect to good deeds he had done as an investment in the hereafter before God. ${ }^{33}$ If funds or investments in the hereafter, are understood as qualified sons/doughters (healthy, educated, and righteous/shalihah) as the priority, not quantity (many children) also thinkable, although it looks artificial. Did not the Prophet said that the whole of human charity lost except three things, one of which is a righteous son/doughter who prayed for his/her parents. ${ }^{34}$

Another argument put forward by people who support that family planning is not prohibited to do 'azal either by the Qur'an or Hadith. This argument is acceptable, for the reason that no forbidden during the prophet treatise in doing 'azal as long as there is a wife permission.

Furthermore, the argument not to leave weak offsprings (al-Nisa'/ 4:9), the verse seems to speak in the context of warning to those who are around the one who is sick with no affection or advising him to consider the welfare of his heirs, do not bequeath his property superfluously to another party. Thus, this verse reminds people to pay attention to the welfare of their offspring so they will become strong persons. ${ }^{35}$ If this verse is then understood to have strong offspring physically, psychologically, and educationally by a way of family planning program can also be accepted in generall by not explicitly interpret the verse.

The next argument is to avoid harm, so that one may follow the family planning program as in the verse 195 of al-Baqarah. This verse actually talks about the command to the believers to spend their wealth in Allah's way, so that the treasure will be preserved, not lost, and even increased. Furthermore, according to al-Rāzī, the verse can be diversely interpreted. One of view is the prohibition to consider that infak in the way of Allah will make someone perished, to avoid hopelessness of God's grace, and give infak in the way of Allah but then damaged or destroyed by mentioning it with riya' (visible to others) and sum ' $a$ h (overheard). ${ }^{36}$ Thus, this verse is not talking about family planning;so, it sems artificial to be a basis of the argument. 
Family planning in certain conditions i.e. in terms of increasing pregnancy intervals, not restrictions, and under certain conditions related to health risk, according to Mahmud Syaltut, scholars agree that it is allowed or lawful. ${ }^{37}$ In general, scholars are more focused on the ability of the family, they do not relate it to the macro socioeconomic conditions of the society in the region. Therefore, the right and responsibility to implement family planning programs should be given to each individual or family, not to the Government as a representative of the community.Under the conditions related to physical health or in a broader sense, related to the well being of the society, I think the government can enforce family planning programs to the citizens.

\section{E. Cocluding Remarks}

In conclusion, family planning is a couple program about when to get pregnant, how many children that they want, by using certain methods (either reversible or permanent) to control the spacing or number of births. When family planning is linked to Islamic reference, some views can be categorized in tanzìm al-nasl and the others can be included intahdìd al-nasl. Family planning is very important as one of solutions to the problem of population explosion that harms the global ecosystem.

In the Islamic view, there is controversy about family planning, especially if it is meant birth control by using permanent methods. Prohibition of the Prophet to marry not for the purpose

\section{Endnotes:}

${ }^{1}$ Law (Act) number 10 of 1992 (10/1992) on the Population Growth and Family Welfare Development, Chapter 1, Article 1, point 12.

${ }^{2}$ WHO, Expert Committe, 1970. whqlibdoc.who.int/.../r.../EURO_R\&S_89.pdf, accessed 15 October 2013. of worship is something contradictory to the Sunnah, because in Islam with marrying someone will get a perfect religion. The purpose of married is not only to get offsprings. If then there is the Hadith which forbids marrying an infertile woman has to be seen in its context.

Furthemore,Islam take notice much to the balance (of justice) including the relation to the human population. As rational creatures, human being need to pay attention to the conditions that exists, whether there is the balance between the population and the ecosystem. If it is not, it is necessary to find a way, one of them isbirthcontrol.

Al-Quran and Hadith do not mention family planning explicitly. However, it implicitly found the permitted argument, such as not prohibiting the Companion who do 'azal in the time of the Prophet. The other arguments put forward in prohibiting the family planning as described above, some seem to be forced, and the others may be accepted if the arguments presented is generally understood and not understood only in context.

When there is out of balance between the number of human populations and the ecosystem, according to me the family planning is not only allowed but essentially required. In such circumstances, the party who deserve the right to determine the implementation of family planning is the community which is in this case can be represented by the government, not just the couples nor thehusbands.

2013.

${ }^{3}$ www.bkkbn.go.id, accessed on 17 July

TrainingMaterialsProgramfor ManagersMUIKKBDistrict City inCentral Java, dated4-7February2013.

5 Paul R. Ehrlich and Anne H. Ehrlich, "The Population Bomb Revisited," The Electronic Journal of Sustainable Development (2009) 1(3), p. 69.

6 Sutyastie Soemilto Remi. "Implikasi Proyeksi Penduduk Indonesia Tahun 2000-2025 Terhadap Pembangunan Berkelanjutan Bidang 
Ekonomi, 2008" www.kemendagri.go.id , 29 September 2013.

| 14:07 WIB

regional kompasiana.com

whatindonews.com, Selasa, 16 Juli 2013

2014.

${ }^{9}$ unic-jakarta.org, accessed on 11 August

2013 20:43 WIB

${ }^{10}$ theglobejournal.com, Sabtu, 27 Juli

${ }^{11}$ Sutyastie Soemilto Remi, "Implikasi

Proyeksi Penduduk Indonesia Tahun 2000-2025

${ }^{12}$ http://www.antaranews.com/berita,

Jum'at, 14 Juni 2013 18:42 WIB.

${ }^{13}$ Mahmmūd Syaltūt, Al-Islām 'Aqīdah wa Syarī'ah (Ttp.: Dār al-Qalam). III: 966, 207-208.

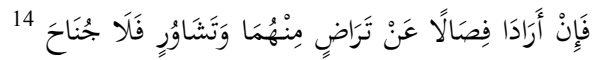

عَلَيْهِهمَا

(If they both decide on weaning, by mutual consent, and after due consultation, there is no blame on them), see in 'Abdullah Y $\overline{\bar{u}}$ susf 'Ali, The Holy Qur'an: Text, Translation and Commentary (Brentwood, Mryland: Amana Corporation, 1409 A.H./1989 A.C.), New Revised Edition, p. 96.

Ghayb, III: 355.

5 Fakhr al-Dīn al-Rāzì, Mafâtīh al-

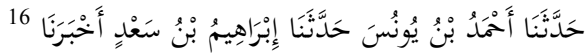

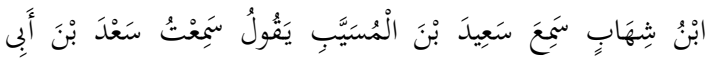

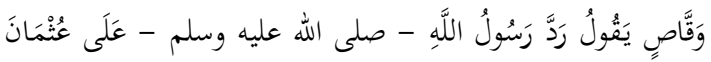

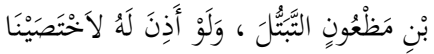

(Al-Bukhāry, Sahīh al-Bukhārīi, Bab mā Yukrah min al-Tabattul (Bandung: Syirkah alMa'ārif li al-țAb' wa al-Nasyr, n.d)). III: 239.

17، Abdullah Yusuf 'Ali, The Holy Qur'an, pp. 655-656.The verses is

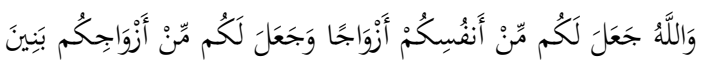

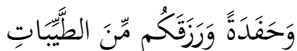

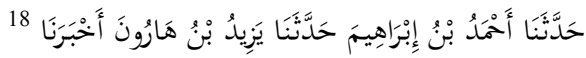

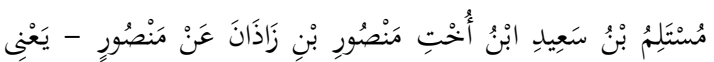

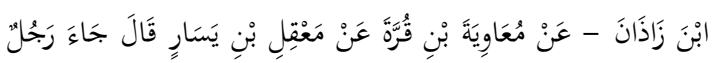

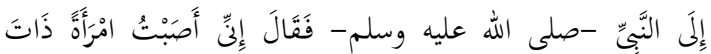

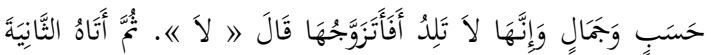

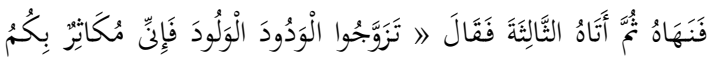
الأُمَمَ

(Abū Dāwūd, Sunan Abū Dāwīd, Bab al-Nahy al- Tazwīj mā lam Yalid, VI: 228. hadis no. 2052)

${ }^{19}$ Q.S. Hūd (11): 6, in 'Abdullah Yusuf 'Ali, The Holy Qur'an, p. 511

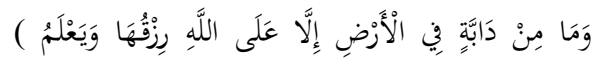

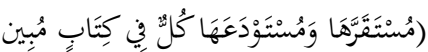

20 'Ali, The Holy Qur'an, p. 339 (Q.S. al-An'àm (6) : 151,

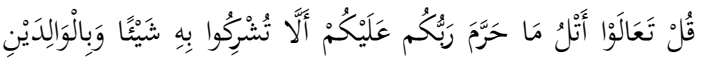

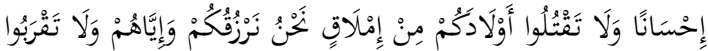

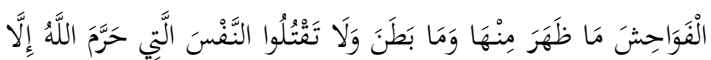

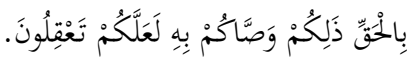

21 'Ali, The Holy Qur'an, p. 339, Q.S. alIsra' (17): 31,

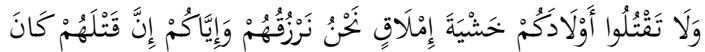

خِطْئًا كَبيرًا

22 'Ali, The Holy Qur'an, p. 1448 (Q.S. al-Hasyr (59) : 18.

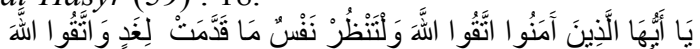

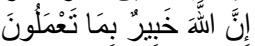

${ }^{23}$ Al-Bukhārī, Sahīh al-Bukhārī, Bāb al'Azl, III, 262.

حدثنا علي بن عبد الله حدثنا سفيان قال عمرو أخبرخي عطاء سمع

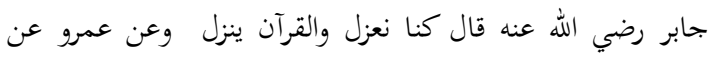
عطاء عن جابر قال كنا نعزل على عهد النبي صلى الله عليه وسلم

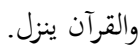

See also in Muslim, Sahịih Muslim, bāb Hukm al'Azl, (Bandung: Dahlan, n.d.), I: 709.

حدثني هارون بن سعيد الأيلي حدثنا عبدالله بن وهب أخبربي معاوية ( يعني ابن صالح ) عن علي بن أبي طلحة عن أبي الوداك

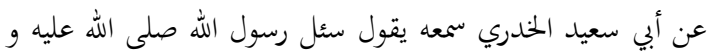

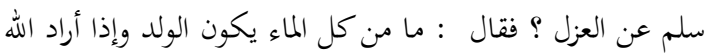
خلق شيء لم يمنعه شيء.

24،Ali, The Holy Qur'an, pp.185-186

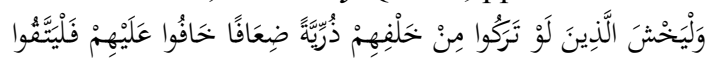

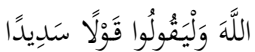

25،Ali, The Holy Qur'an, p. 178,

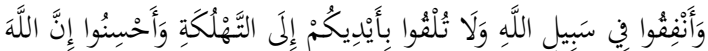

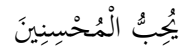

${ }^{26}$ Louis Ma'lūf, Al-Munjid fì al-Lughah wa al-A lām (Beirut: Dār al-Masyriq, 1986), p. 26.

${ }^{27}$ Ibnu Taimiyah, Majmū' Fatāwā Ibnu Taymiyah, III: 94.

عن أنس بن مالك قال : قال رسول الله صلى الله 28 عليه وسلم : \ا من تزوج فقد استكمل نصف الإيمان ، فليتق الله في النصف الباقي 
(Al-Țabrānī, al-Mu jam al-Awsaţ, Bāb al Mìm man Ismuh Muhammad, XVI: 438)

${ }^{29}$ Read in Naqiyah Mukhtar, "Mengurai Nikah Sirri," Al-Manāhij, Vol. VI, no. 12, Juli 2012, pp. 254-156.

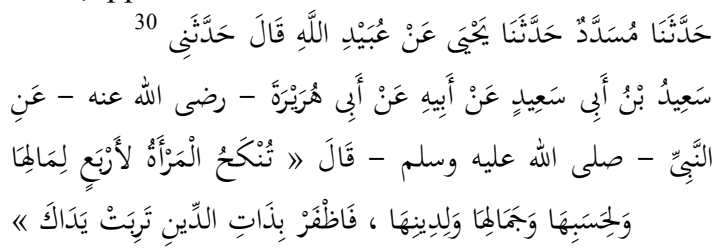

(Al-Bukhārī, Sahīḥ al-Bukhārī, Bāb alIkfā' fi al-Dìn, Hadis no 5090).

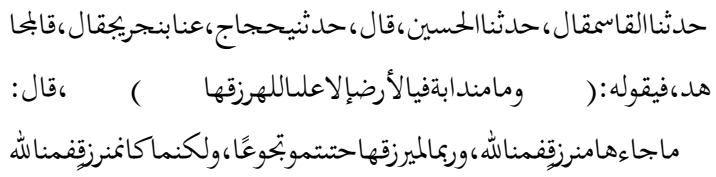

Baca dalam al-Ṭabarī, Tafsīr al-Ṭabarī, $\mathrm{XV}: 240$.

${ }^{32}$ www.antaranews.com, Selasa, 18 Juni 2013 09:30 WIB

${ }^{33}$ Ibn Kasīr, Tafsìr al-Qur'ān al-'Aāim (Ttp: Dār Taibah li al-Nasyr wa al-Tawzī, 1999), VIII: 77.

$$
\begin{aligned}
& \text { عن أبي هريرة : أن رسول الله صلى الله عليه و سلم } 34 \\
& \text { قال ( إذا مات الإنسان انقطع عنه عمله إلا من ثلاثة إلا من } \\
& \text { صدقة جارية أو علم ينتفع به أو ولد صالح يدعو له ) } \\
& \text { Muslim, Sahīh al-Muslim, Bāb mā }
\end{aligned}
$$
Yalḥaq al-Insān min al-Ṣawāb Ba'da Wafātih, III: 1255.

${ }^{35}$ Mengenai ragam pendapat tentang penafsiran ayat ini dapat dibaca dalam tafsir alRāzī, Mafātīhal-Ghayb, V: 72.

${ }^{36}$ Ibid., III: 153 .

${ }^{37}$ Mahmūd Syaltūt, al-Fatāwā: Dirāsat al-Musykilāt al-Muslim al-Mu'āsir fí Hayātih alYawmiyyah wa al-'Ammah (Cairo: Dār alSyurūq, 1421 A.H./2001), pp. 297-298

\section{BIBLIOGRAPHY}

'Ali, 'Abdullah Yūsuf. The Holy Qur'an: Text, Translation and Commentary, New Revised Edition. Brentwood, Mryland: Amana Corporation. 1409 A.H./1989 A.C.

Al-Bukhāry. Sahịh al-Bukhārī. Bandung: Syirkah al-Ma'ārif li al-Tab' wa alNasyr, n.d.
Ehrlich, Paul R. and Anne H. Ehrlich. "The Population Bomb Revisited," The Electronic Journal of Sustainable Development, I, 3, (2009).

Ibn Kașìr. Tafsīr al-Qur'ān al-'Ażīm. Ttp: Dār Țaibah li 1-Nasyr wa alTawzī', 1999.

Ibnu Taymiyah. "Majmū' Fatāwā Ibnu Taymiyah", al Maktabah al-

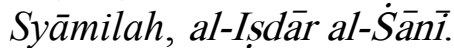

Ma'lūf, Louis. Al-Munjid fí al-Lughah wa al-A làm. Beirut: Dār al-Masyriq, 1986.

Mukhtar, Naqiyah. "Mengurai Nikah Sirri," in Al-Manāhij, Vol. VI, number 12, Juli 2012.

Muslim. Sahīh Muslim. Bandung: Dahlan, n.d.

Remi, Sutyastie Soemilto. "Implikasi Proyeksi Penduduk Indonesia Tahun 2000-2025 Terhadap Pembangunan Berkelanjucan Bidang Ekon, 2008" www.kemendagri.go.id, accessed 29 September 2013.

Al-Rāzī, Fakhr al-Din. "Mafătīh alGhayb, dalam al Maktabah alSyāmilah, al-Ișdār al-S̈̄̄̄í.

Syaltūt, Maḥmūd. Al-Islām 'Aqīdah wa Syarī'ah. Np.: Dār al-Qalam, Nd.

$$
\text { al-Fatāwā: Dirāsat al- }
$$

Musykilät al-Muslim al-Mu'āsir fi Hayātih al-Yawmiyyah wa al-'Ammah. Cairo: Dār al-Syurūq, 1421 A.H./2001.

Al-Tabarī, “Tafsīr al-Tabarī”, alMaktabah al-Syāmilah, al-Ișār al$\dot{S} \bar{a} n \bar{i}$.

Al-Ṭabrān̄̄, "al-Mu'jam al-Awsaț”, alMaktabah al-Syāmilah, al-Ișdār al$\dot{S} \bar{a} n \bar{i}$

Training Materials Program for Managers MUIKKB District City in Central Java, dated4-7February2013.

WHO, Expert Committe, 1970. whqlibdoc.who.int, accessed 15 October 2013

regional.kompasiana.com 
theglobejournal.com, Sabtu, 27 Juli 2013. unic-jakarta.org, 11 August 2014. whatindonews.com, Selasa, 16 Juli 2013. www.antaranews.com, Jum'at, 14 Juni 2013. 